\title{
Sciendo \\ ANALYSIS OF DEVICE FAILURE
IN THE MECHANICAL PRODUCTION PLANT
}

doi:10.2478/mape-2018-0013

Date of submission of the article to the Editor: 05/2018

Date of acceptance of the article by the Editor: 07/2018

MAPE 2018, volume 1, issue 1, pp. 93-99

Dr inż. Jacek Sitko

Silesian University of Technology, Poland

Ing. Rastislav Mikuš, PhD.

Slovak University of Agriculture Nitra, Slovak Republic

Prof. Ing. Pavol Božek, CSc.

Slovak University of Technology, Bratislava, Slovak Republic

\begin{abstract}
The article evaluates the failure rate of devices in the Mechanical Processing Plant using a traditional quality tool, the Pareto-Lorenzo diagram. A comparative analysis of failure rates was performed, recorded in repair, inspection and maintenance card. Then, changes were proposed in order to reduce failure rates and earlier detection of equipment malfunctions.

In order to analyze the failure rate of grain washer equipment during thick coal preparation process, one quality management tools was used - the Pareto-Lorenzo diagram.

In this case, it is important to assess the mechanical failure of devices, and demonstrating which devices generate most repairs. Based on materials made available by the mine, such as:

- Repair, inspection and maintenance cards,

- Device cards,

- DTR documentation.

Quantitative and qualitative assessment the most frequently occurring mechanical failures during operation of devices in process enrichment of coarse sizes was carried out. An attempt was made to assess failure rate of devices on a grain washer. A comparative analysis of failure rates in 2015-2017 recorded in the repair, inspection and maintenance card was carried out.

Then, changes were proposed to stand, in order reduce failure rates, and earlier detection equipment malfunctions.
\end{abstract}

Keywords: plant, failure, analysis, repair, quality

\section{INTRODUCTION}

In the Mechanical Coal Processing Plant in KWK, whose nominal capacity is $750 \mathrm{Mg} / \mathrm{h}$, coal is enriched the class of $120 \div 16 \mathrm{~mm}$ in heavy liquid, while it has crude after separation of grain class $4(6) \div 0 \mathrm{~mm}$ is enriched in 32.1 type thermal coal is suitable for the processing plant.

On the surface, coal spoil in grain size $200 \div 0 \mathrm{~mm}$ is pulled out with two glass panes. Then it is directed to Vibrating Screen WK1 with $120 \mathrm{~mm}$ holes.

After passing through transfer belt (removal of scrap, wood, etc.), upper product of the trommel screen is crushed in KWK-100UM grinder for granulation below $120 \mathrm{~mm}$. However, the bottom product of trommel screen and crushed grain class $+120 \mathrm{~mm}$ are combined and collected in two tanks ( $A$ and $B$ ) of crude coal with a total capacity of $3600 \mathrm{Mg}$ (A 800 tons and $B 2600$ tons). From the tanks, coal is fed to pre-classification node, equipped with a PZ 3090 screen with $16 \mathrm{~mm}$ holes. The plant has option of pre-sizing fines from raw coal stored in the tank

With a capacity of $800 \mathrm{Mg}$. For this purpose, two screens are used, which are built-in PWP $1-2 \times 4.5$ equipped with decks with hole sizes, respectively: first $16 / 20$ and second $16 \mathrm{~mm}$. 
From the last screen upper product is directed to pre-classification node, while bottom products of both screens can be already routed alternatively, for loading into wagons, piles or to heat and power plant (Biały, 2017).

The upper product of the PZ 3090 screening machine, the grain class $+16 \mathrm{~mm}$, is enriched with a two-product heavy-duty enrichment fluid type Drewboy 3.2. Enrichment takes place in a suspension concentrate in a heavy liquid with a specific gravity of $1.6 \mathrm{~g} / \mathrm{cm}^{3}$. The resulting carbon concentrate is dewatered on a permanent sieve and a PWP1 vibrating screen with $1 \mathrm{~mm}$ slotted sieves. The sieves from the solid sieve and from first part of PWP1 screen are directed to working liquid reservoir for reuse in enrichment process, while filtration from second part of screen, which was mainly caused by use of sprays - part of suspension after recuperation and water from the clean water tanks are treated as product for regeneration.

By means of a conveyor system, the dehydrated concentrate is directed to a fixed grate with $30 \mathrm{~mm}$ holes. Grain class $+30 \mathrm{~mm}$ is fed to the screen PWP1 $1.5 \times 3,75$ with 40 and 80 $\mathrm{mm}$ holes. The upper product is collected in tanks and the bottom products of trommel screen are classified on two screens PWP1 $1.8 \times 5.25$ built-in positively with holes: $20 \mathrm{~mm}$ and $25 \mathrm{~mm}$ and $31 \mathrm{~mm}$, respectively.

The separated grain classes are already commercial products and are directed to appropriate tanks.

The bottom product, which has been separated on a fixed grate, is directed to WE vibrating screens, which decks are equipped with sieves with 8,25 and $30 \mathrm{~mm}$ holes. The separated grain classes are commercial products, they are components of commercial products and are led to appropriate tanks. The class $>30 \mathrm{~mm}$ is crushed by means of a KD two-roll crusher and, via the bucket elevator B-300, it is recycled back to screens (www.mifama.com.pl).

The above-mentioned devices undergo continuous production operations, are subject to cyclical wear and increased failure frequency. The most common reason for unexpected breaks in production is machine failure rate (Brodny and Szurgacz, 2017).

Stages the analysis carried out using Pareto-Lorenzo diagram:

1. Collection of data on repairs of grain washer equipment.

2. Calculation of cumulative percentages for individual failures.

3. Making a diagram.

4. Analysis of the drawn diagram.

The process of enrichment coarse assortments (over 16mm) on a grain washer uses devices listed in Table 1 and 4 tanks, which are not analyzed because they do not have a maintenance, inspection and renovation card.

One of the tanks stores raw coal, tanks no. 23 and 24 store a magnetite suspension, next tank no. 25 stores magnetite. Final waste tanks and classified coal are also not included in the analysis. Then, the sum of all failures on individual devices was collected in Table 1. 
Table 1

Sum repairs of grain washer equipment.

\begin{tabular}{|c|l|c|}
\hline Device number & \multicolumn{1}{|c|}{ Device name } & Sum of repairs \\
\hline $\mathbf{1}$ & Trapezoidal feeder WPT 3.02 & $\mathbf{1 2}$ \\
\hline $\mathbf{2}$ & Screening machine PZ 3090 & $\mathbf{2 1}$ \\
\hline $\mathbf{3}$ & Belt conveyor B-1040 & $\mathbf{1 6}$ \\
\hline $\mathbf{4}$ & Screening machine PWP1 2.2x4.5 & $\mathbf{2 7}$ \\
\hline $\mathbf{5}$ & Heavy liquid enrichment DREWBOY & $\mathbf{2 2}$ \\
\hline $\mathbf{6}$ & Screening machine PWP1 3x5.25 & $\mathbf{4}$ \\
\hline $\mathbf{8}$ & Belt conveyor B-1000 & $\mathbf{4}$ \\
\hline $\mathbf{9}$ & Belt conveyor B-1010 & $\mathbf{1 1}$ \\
\hline $\mathbf{1 0}$ & Pomp OŁ 150 & $\mathbf{1 0}$ \\
\hline $\mathbf{1 1}$ & Pomp OŁ 80 & $\mathbf{1}$ \\
\hline $\mathbf{1 2}$ & Rekuperator reserve & $\mathbf{7}$ \\
\hline $\mathbf{1 3}$ & Rekuperator & $\mathbf{2}$ \\
\hline $\mathbf{1 4}$ & Pomp OŁ 150 & $\mathbf{2}$ \\
\hline $\mathbf{1 5}$ & Hydrocyklon Krebs D-15 & $\mathbf{1}$ \\
\hline $\mathbf{1 6}$ & Mill MK 900x900 & $\mathbf{1 2}$ \\
\hline $\mathbf{1 7}$ & Screening machine PWP 1K 1.5x3.75 & $\mathbf{1 3}$ \\
\hline $\mathbf{1 8}$ & Screening machine PWP 1K 1.8x5.5 & $\mathbf{6}$ \\
\hline $\mathbf{1 9}$ & Screening machine PWP 1K 1.8x5.5 & $\mathbf{5}$ \\
\hline $\mathbf{2 0}$ & Belt conveyor B-800 & $\mathbf{3}$ \\
\hline $\mathbf{2 1}$ & Belt conveyor B-630 & $\mathbf{4}$ \\
\hline $\mathbf{2 2}$ & Belt conveyor B-1030 & $\mathbf{7}$ \\
\hline & Belt conveyor B-1020 & \\
\hline
\end{tabular}

The next step was to calculate the cumulative percentage values of repairs, table 2 .

Table 2

Accumulated percentages for device repairs

\begin{tabular}{|c|l|c|c|}
\hline Number devices & \multicolumn{1}{|c|}{ The type of device } & $\begin{array}{c}\text { Number } \\
\text { of repairs }\end{array}$ & $\begin{array}{c}\text { Percentage } \\
\text { of repairs }\end{array}$ \\
\hline $\mathbf{5}$ & Heavy liquid enrichment DREWBOY 3,2 & $\mathbf{2 7}$ & $14,1 \%$ \\
\hline $\mathbf{6}$ & Screening machine PWP1 3x5.25 & $\mathbf{2 2}$ & $11,5 \%$ \\
\hline $\mathbf{2}$ & Screening machine PZ 3090 & $\mathbf{2 1}$ & $10,9 \%$ \\
\hline $\mathbf{4}$ & Screening machine PWP1 2.2x4.5 & $\mathbf{1 6}$ & $8,3 \%$ \\
\hline $\mathbf{1 7}$ & Screening machine PWP 1K 1.8x5.5 & $\mathbf{1 3}$ & $6,8 \%$ \\
\hline $\mathbf{1}$ & Belt conveyor WPT 3.02 & $\mathbf{1 2}$ & $6,3 \%$ \\
\hline $\mathbf{1 6}$ & Screening machine PWP 1K 1.5x3.75 & $\mathbf{1 2}$ & $6,3 \%$ \\
\hline $\mathbf{9}$ & Pomp OŁ 150 & $\mathbf{1 1}$ & $5,7 \%$ \\
\hline $\mathbf{1 0}$ & Pomp OŁ 80 & $\mathbf{1 0}$ & $5,2 \%$ \\
\hline $\mathbf{1 2}$ & Rekuperator & $\mathbf{7}$ & $3,6 \%$ \\
\hline $\mathbf{2 2}$ & Belt conveyor B-1040 & $\mathbf{7}$ & $3,6 \%$ \\
\hline $\mathbf{1 8}$ & Screening machine PWP 1K 1.8x5.5 & $\mathbf{6}$ & $3,1 \%$ \\
\hline $\mathbf{1 9}$ & Belt conveyor B-800 & $\mathbf{5}$ & $2,6 \%$ \\
\hline $\mathbf{7}$ & Belt conveyor B-1000 & $\mathbf{4}$ & $2,1 \%$ \\
\hline $\mathbf{8}$ & Belt conveyor B-1010 & $\mathbf{4}$ & $2,1 \%$ \\
\hline $\mathbf{2 1}$ & Belt conveyor B-1020 & $\mathbf{4}$ & $2,1 \%$ \\
\hline $\mathbf{2 0}$ & Belt conveyor B-630 & $\mathbf{3}$ & $1,6 \%$ \\
\hline $\mathbf{3}$ & Belt conveyor B-1030 & $\mathbf{2}$ & $1,0 \%$ \\
\hline $\mathbf{1 3}$ & Pomp OŁ 150 & $\mathbf{2}$ & $1,0 \%$ \\
\hline $\mathbf{1 4}$ & Hydrocyklon Krebs D-15 & $\mathbf{2}$ & $1,0 \%$ \\
\hline $\mathbf{1 1}$ & Rekuperator reserve & $\mathbf{1}$ & $0,5 \%$ \\
\hline $\mathbf{1 5}$ & Mill 900x900 & $\mathbf{1}$ & \\
\hline & & & $0,5 \%$ \\
\hline
\end{tabular}




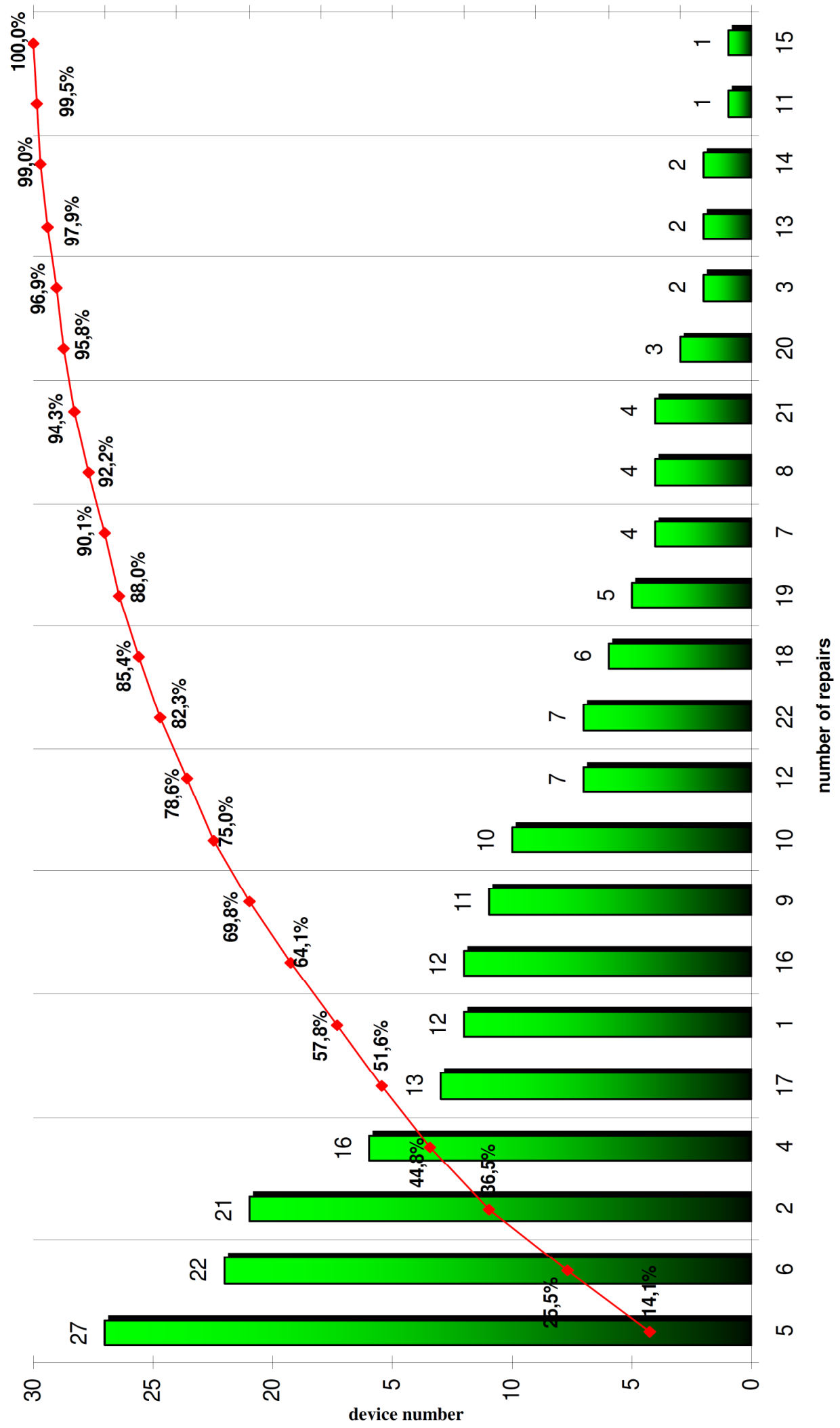

Fig. 1. Pareto - Lorenzo diagram 
The analysis of Pareto-Lorenzo diagram (Fig. 1) shows that the largest number of repairs 78.6\% generates 10 machines:

- DREWBOY 3.2 heavy liquid enrichment

- Screening machine PWP1 3 x 5.25

- Screening machine PZ 3090

- Screening machine PWP1 $2.2 \times 4.5$

- Screening machine PWP $1 \mathrm{~K} 1.8 \times 5.5$

- WPT 3.02 trapezoidal feed

- Screening machine PWP $1 \mathrm{~K} 1.5$ x 3.75

- OŁ 150 pump

- OŁ 80 pump

Considering the percentage of these 10 machines, it can be stated that a total of $45.5 \%$ of types of devices causes as much as $78.6 \%$ of failures. The remaining 12 devices cause $21.4 \%$ of repairs. It follows that first 10 machines should be analyzed in first place.

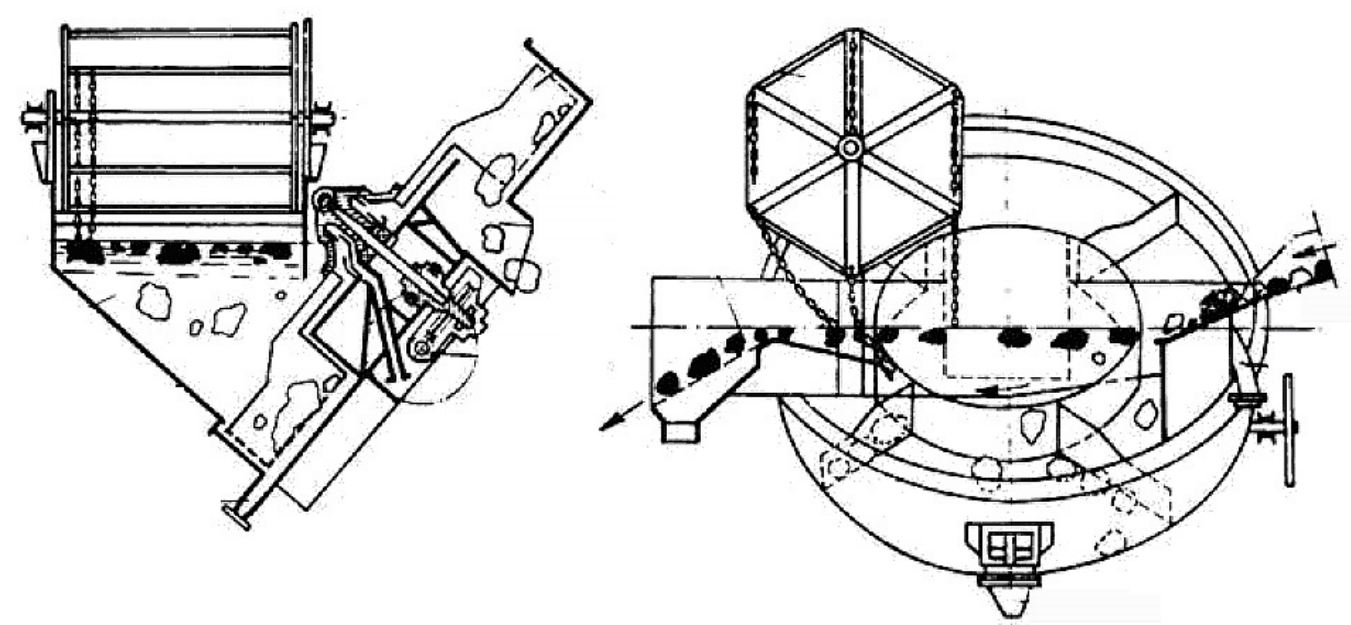

Fig. 2. Drewboy 3.2. Heavy liquid enrichment

The most consuming device on a grains washer is Drewboy 3.2 (2), the element most often mentioned in it is sheet metal. In the group of devices causing most repairs, there are up to 5 screens, which is $50 \%$ of the most emergency ones.

Screen elements are exposed to constant friction and vibrations, which is why their parts wear out fairly quickly (Operation and Maintenance Manual, 2015)

Pumps, too are repaired many times, but in approx. $50 \%$ of cases, failures are exchanged for new ones.

\section{IMPROVING THE RELIABILITY AND EFFICIENCY OF PROCESS}

The efficiency of production process depends to a large extent on failure-free operation the equipment at the stage mechanical processing of coal, where commercial products are created. Raw spoil is not sold. It is necessary to look at correctness the work of devices included in coal enrichment process (Blaschke, 2009).

For analysis, the process of enrichment coarse grain sizes was chosen.

After the analysis using the Pareto-Lorenzo diagram, information on machines that generate most failures was obtained.

Machines that required frequent repairs:

- Drewboy enrichment 3.2,

- trapezoidal feed,

- five screens of various types, 
- OŁ pumps.

The most common repairs on given devices were:

a) Drewboy 3.2 enrichment:

- replacement of sheets,

- bearing replacement,

- replacement of sieves.

b) Trapezoidal feeder

- replacement of break plates,

- bearing replacement,

- spring replacement.

c) Screeners of various types

- replacement of beams,

- bearing replacement,

- spring replacement.

d) Pump

- pump replacement,

- replacement of the rotor.

In order to improve the reliability of equipment, it is recommended to perform more frequent inspections on machines that generated most repairs. It is important to avoid malfunctions during use process (Michalski and Kunart, 2017). A portable infrared camera can be a helpful device during review. It is ideal for carrying out maintenance inspections and scheduled electrical and mechanical inspections. Currently, thermal imaging cameras are used by rescuers during rescue operations, for early detection of endogenous fires (Blaschke, 1984). Because every mechanical component, before it fails, produces heat, it is easy to find damage.

The guarantee high durability of devices and reliability during operation it is use of technical diagnostics that correctly determines technical condition machine (Zasadzeń and SkotnickaZasadzień, 2013).

The basic tasks of machine diagnostics are the detection of emergency states and their identification.

Measurements using a thermal imaging camera allow you to effectively determine technical states of machines and devices, thereby limiting emergency states that are associated with reduction of production costs and avoiding losses of enterprise. A thermal imaging camera is an example of non-contact thermometry. It is used for the diagnostics machines and devices; in particular, it can be used to find potential damage to electrical devices (machine drives, pumps).

The camera is a lightweight device, easy to use, combines functions of a thermal imaging camera and a digital camera. LED diodes illuminate tested object, which enables efficient work in an unlit environment (www.flir.com).

Computer visual and thermographic analysis of examined objects is possible thanks to software that is attached to the camera (www.wichary.eu). The camera converts thermal radiation or invisible infrared into thermograms ready for analysis. This device performs noncontact temperature measurement, it also has the function of digital photography.

\section{CONCLUSION}

1. Technical diagnostics of devices has a big impact on the efficiency of detecting irregularities and defects of the coal enrichment process.

2. The devices generating the greatest amount of downtime include heavy fluid concentrator, screens and pumps. 
3. It is recommended to carry out inspections, observations between main inspections with the use of devices such as a vibrometric pen and a thermal imaging camera in order to detect irregularities in the operation of grain drilling equipment.

4. It is proposed to replace sheets with steel plates with a rubber coating, which should reduce the level of their consumption and the need for downtime associated with their replacement and improve working conditions by reducing noise.

5. Replacing sheet sieves perforated with polyurethane (PU) or rubber screens, which will extend the time between sieves replacements and reduce downtimes related to their replacement and cleaning of the sieve deck.

\section{ACKNOWLEDGEMENTS}

The paper is the result of statutory research carried out at the Institute of Production Engineering at the Faculty of Organization and Management of the Silesian University of Technology as part of a project number 13/030/BK_18/0039 called "Development of intelligent production methods as well as work and life environments in the context of production engineering challenges".

\section{REFERENCES}

Biały, W. (2017). Application of quality management tools for evaluating the failure frequency of cutter loader and plough mining systems. -Arch. Mining Sci. 2017 vol. 62 iss. 2, s. 243-252.

Blaschke, S. (1984). Przeróbka mechaniczna kopalin Część II. Katowice: Wydawnictwo „Śląsk”.

Blaschke, W. (2009). Przeróbka węgla kamiennego - wzbogacanie grawitacyjne, Kraków: Wydawnictwo Instytutu Gospodarki Surowcami Mineralnymi i Energią PAN, 2009.

Brodny, J. and Szurgacz, D. (2017). An innovative system to test components of mining machinery control hydraulics. 17th International Multidisciplinary Scientific GeoConference. SGEM 2017, 29 June - 5 July 2017, Albena, Bulgaria. Conference proceedings. Vol. 17, Science and technologies in geology, exploration and mining. Iss. 13, Exploration and mining. Sofia : STEF92 Technology pp. 47-54,

Dokumentacja Techniczno-Ruchowa, 2015

FLIR® Systems, Inc. (2018). [online] Available at: www.flir.com

Grupa Powen-Wafapomp SA. (2018). [online] Available at: www.powen.pl

Michalski, K. and Kunat, D. (2017). Opracowanie sposobu prowadzenia analizy awaryjności wtryskarek w oparciu o metodę FMEA w „Systemy Wspomagania w Inżynierii Produkcji. Jakość, Bezpieczeństwo, Środowisko", pod red. A. Kuboszka i E. Milewskiej, Vol. 6, issue 7, P.A. Nova, Gliwice . pp. 183-190.

MIFAMA OPA CARBO (2016). [online] Available at: www.mifama.com.pl

WICHARY Technologies. (2018). [online] Available at: www.wichary.eu

Zasadzeń, M. and Skotnicka-Zasadzień, B. (2013). Zastosowanie miar niezawodności do analizy awaryjności kluczowych maszyn w przedsiębiorstwie produkcyjnym - studium przypadku Systemy Wspomagania w Inżynierii Produkcji, Wydawnictwo P.A. NOVA, pp. 165-175. 